\title{
JUST LIKE BLACK, ONLY BETTER: POOR WHITE IN ANTEBELLUM SOUTH OF AMERICA DEPICTED IN SOLOMON NORTHUP'S NOVEL TWELVE YEARS AS A SLAVE
}

\author{
Rasiah, Ansor Putra, Arman, Fina Amalia Masri, and Suci Rahmi Pardilla \\ Universitas Halu Oleo \\ Email: rasiahfib@uho.ac.id
}

\begin{abstract}
(Title: Just Like Black, Only Better: Poor White in Antebellum South of America Depicted in Solomon Northup's Novel "Twelve Years as A Slave"). Antebellum era, the period before the Civil War occurred or before the year 1861, in the United States is used to relate to the enslavement of black Americans. In fact, the era was not merely about black, but also poor white. This study is purposed to describe the poor whites' life in antebellum America as reflected in Twelve Years As A Slave (1855), a narrative biography novel written by Solomon Northup. Set up the story in New York, Washington DC, and New Orleans, the author (and focalizer at once) told the story based on his own experience as a black who was captivated and sold into slavery for twelve years. Although the novel centered its story on black characters, it also reflected the life of poor whites who were also being "enslaved" by their white counterparts. Through the sociology of literature perspective, this study reveals that the character of poor white that represented through John M. Tibeats, Armsby, and James H. Burch came from Great Britain especially from Ireland. Mostly, they moved to America as incarcerated people. They lived in the poverty and some of them were vagrants and petty criminals. Poor white during the antebellum era in America was positioned in the lower social level. They were "enslaved" by their white master but better compared to the black slaves. It can be noticed that poor whites were positioned at a low social level because of the socioeconomic problem, while blacks were the racial difference.
\end{abstract}

Keywords: antebellum America, poor white, slavery, social class, American literature

\section{INTRODUCTION}

From the antebellum period to today, Southern white elites are terrified of poor whites and black workers joining hands - because they know it's an existential threat to their power.

(Keri Leigh Merritt, in Jacobin Magazine, 2019)

Slavery has been the important issue in the American South history and literature. as The specter of slavery inherited white supremacy and severe class divisions (Merritt, 2017). Severe class division, in particular, has also raised a class split within white people in the antebellum Deep South. According to Stallard (2016), the antebellum period in South and North America was defined by the increasing penetration of the global and national capitalistic market system into everyday life and economic activity. Poor white class is one of the fruits of it.

Flynt (2004) identified poor white as the historical classification for an American socio-cultural group of the South that generally Western and/or Northern European ancestry, with origins in the Southern United States and in Appalachia. They formerly were classified as a social status (Seabrook ,2012) in the Antebellum South, and consisting of white, agrarian, economically disadvantaged laborers or squatters, who usually owned neither land nor slaves (Weston 2012). In particular contemporary contexts, the term of poor white is still operated to refer to their descendants regardless of present economic status. They differ notably in regard to their history and culture. 
Throughout American history, the term of poor white has commonly been referred to various terms and commonly are often considered derogatory (Price, 2004). Price (2004) explained that poor is used to demonstrate a low position, while "white" was used to subjugate rather than to classify. Formerly, the white Southern elite used the term poor white to those who considered it an "oxymoron", that was the elements of society they viewed as undesirable, lesser, or antisocial. The other populer terms, poor white also are known as rednecks, 'hillbillies' (in Appalachia), 'crackers' (in Georgia and Florida), and 'white trash'. Flynt (2004) argued that one difficulty in defining poor whites stems from the diverse ways in which the phrase has been used. It has been applied to economic and social classes as well to cultural and ethical values. In the other hand, the other Southern proslavery, according to Wray (2006), that a "degenerate" class of poor whites in the South existed not because of social or economic factors, but rather as the result of "natural inferiority," the inherited depravity that comes from generations of "defective blood." As proof, they pointed to the existence of white trash in non-slave states.

The existence of poor whites in the South in the era of antebellum has a significant portion of southern society and become visible over the North-South sectional crisis over slavery. However, according to Glossner (2016), as a topic of historical analysis, the poor whites of the antebellum U.S. South have received little sustained interest. Glossner (2016) so far states thathHistorians have pointed to white supremacy to explain the lack of poor white resistance to the slave labor system as well as the development of a biracial class consciousness. Similarly, Merritt (2017) said that poor (and working-class) whites have almost been left out of US country's narrative because in acknowledging their existence would raise a paradox in the existence of America as a Democratic state and more specifically a denial of the American dream as well as a worsening wound in the heart of American Exceptionalism. Moreover, Merritt states that the denying of poor whites in the
South's narrative is for a very political reason: the idea of a "solid white South," wherein all classes of whites vote the same way and have the same interests, allows the dissemination of the Confederate "Lost Cause" narrative, as well as the incorrect (but persistent) notion that all whites are elevated by racism.

In the American literature, poor white also reflected through almost all novels or poetry which put slavery as the theme of the works. Say, writers such as Margaret Mitchell, Flannery O'Connor, Erskine Caldwell, and James Dickey, and the recent decade, Edward P Jones, and Alice Randall, even Sherwood Anderson entitled his novel explicitly Poor White, to indicate that poor white exist in American society. However, as aforementioned they are still limited to be problematized as case study. Black enslavement issues seemed more interesting and crucial topic to be discussed for the historians or literary studiers rather than poor whites. In reality, as showed by Merritt (2017), class conflict among white Southerners has a long and radical history, as does interaction and political cooperation between poor whites and blacks, not only during antebellum era, but also early Reconstruction or even the Civil Rights Movement. So, investigating poor white through literary work can also clarify the multiproblem of race and class in the American society.

This study is aimed to describe the life of poor white in antebellum South that represented through the novel Twelve Years As A Slave written by Solomon Northup. It is a narrative biography novel written based on the experience of Solomon Northup when he was kidnapped and sold into slavery during twelve years as a slave. In the novel, Solomon was described himself as a free black man living in upstate New York with his family in the 1840s. $\mathrm{He}$ is a carpenter and a talented violin player. It is told that, one day, two men approached him and asked if he would accompany them and play his fiddle as they travel to Washington DC to the circus they work for. Solomon went along with them. Unfortunately, he was drugged and woken up in what he discovered was a slave pen within view of the Capitol. 
Burch, a cruel slave trader, beated Solomon and told him never to mention that he was from the North and that he was kidnapped. Solomon was intimidated into submission and despairing about his new situation. He and several other slaves were taken down South to Louisiana to be sold. Solomon witnessed firsthand the horror of slavery in Southern States.

Looking at the glance of the story, it could be noticed the character of Burch as one of the people who fiddling Solomon and sold as a slave. He is a white man, but lived poorly. $\mathrm{He}$ and his friend named Armsby worked for white planter as overseer, and treated their master's slaves cruelly and brutes. Solomon as the leading character in the story pictured the poor whites as the betrayer, live under poverty, and petty criminals. They existed and became a part of society and social segment in the United States, particularly in the Deep South.

The present study noticed that poor white have to be an important issue that can be used to clarify triggering tensions related to race and class in antebellum up to recent periods. So, by using sociology of literature perspective, this study tried to reveal the life of poor white in antebellum era. The sociology of literature is a subfield of the sociology of culture. It studies the social production of literature and its social implication. Wellek and Warren stated:

Literature is a social institution, using as its medium language, asocial creation. They are conventions and norm which could have arisen only in society. But, furthermore, literature represents 'life' and 'life' is, in large measure, a social reality, even though the natural world and the inner or subjective world of the individual have also been objects of literary 'imitation'. The poet himself is a member of society, possessed of a specific social status; he receives some degree of social recognition and reward; headdresses an audience, however hypothetical (1976: 94).

So, literary work is regarded as the segment of society and sociology of literature is a growing body of critical theory that studies literary works in the context of social institutions and factors, the world view of the writer, and the ideology of the gatekeepers of literature. As an approach to understand, analyze, and to evaluate the literary works by paying particular attention to the social aspects, literature is no longer regarded as something an autonomous. The existence of literary works, thus always to be understood in relation to aspects of society. Literature was considered as one of the socio-cultural phenomena, a product of society (Swingewood \& Laurenson 1972). The authors of literary works are considered as community members in creating the literary works, certainly cannot be dissociated from the community where they live, so that what is portrayed. By this perspective, this study work to trace the origin, social class, and the relation of poor white to white master and black slaves in antebellum South as reflected in Twelve years as A slave.

\section{METHOD}

The primary data in this study is the text of novel Twelve Years As A Slave written by Solomon Northup and published in 1855 . Noted the year of its publication, the novel is published in antebellum era. So, it assumed that it can become a socio-cultural and historical references in picturing the life of the American in the past time, particularly poor whites' life. The data also supported by secondary data that taken from history and social books, as well as another novel or literary works that reflected the same issue.

Data collected through annotating and cataloging, and analyzed by using descriptiveinterpretively technique. Descriptiveinterpretively technique operated through sociology of literature approach by interpreting data that closely related to socio-cultural and historical phenomena of poor white in antebellum America that reflected connotatively or denotatively in the novel.

\section{RESULTS AND DISCUSSION Results}

Twelve Years a Slave pictured poor whites either implicitly or explicitly. Along with the horror experience of being enslaved, the other depicted the origin of poor white 
that implicitly seen from few characters in this novel, and their social class seen from their relation to white master and black slaves.

The origin of the poor white depicted in the Twelve Years As A Slave could be noticed through their appearance. They mostly described as large, dark-red, full face and flush complexion, and five feet ten inches high. This appearance commonly marked as the Irish. Besides appearances, poor white also described through their temperament. They characterized as cruel, cunning, grossly coarse, sinister and repugnant. There are several reason why they acted as such, one of them is because they are incarcerated people that lived under pressure. It is in fact fazed their temper.

The other aspect of poor white represented through this novel is its social class. They are depicted being in lower social class compared to white master, but higher than black slaves. In the novel, those poor whites, like Mr. Chaplin and Armsby are depicted as overseers and slave trades, besides they work as carpenters for their white masters. As the overseers, they controlled the black slaves who worked in white master plantation. So, in the classification of social stratum, they are below the white master. However, the profession as overseer also defined their status upper than black slaves that defined as chattel. Besides the profession, they also depicted lived under poverty. They live with less medical treatment and haven't enough food to eat. The highlight of the poor whites' life in antebellum South in this novel is displayed in the following table.

Table 1. The Result of Study

\begin{tabular}{|c|c|c|}
\hline No & Finding & Unit Analysis \\
\hline 1. & Origins of poor white & $\begin{array}{ll} & \text { Appearance related to the national identity and figure } \\
\text { - } & \text { Temperament related to their emotional status }\end{array}$ \\
\hline 2. & Poor white social class & $\begin{array}{l}\text { - Profession related to their economic status and welfare } \\
\text { - Relation to those white master related to their social class } \\
\text { - Relation to those black slaves related to social and economic } \\
\text { as well as race status }\end{array}$ \\
\hline
\end{tabular}

\section{Discussion}

\section{The Origin of the Poor White}

In Twelve Years a Slave novel by Solomon Northup, the origin of poor white implicitly could be depicted from few characters in this novel. There are no clear statement or conversation that can lead us to know where the poor whites in America came from. However, the appearance the character could be identified to relate to the specific nationality and regions. Solomon describe the poor white through the character of Burch as in the following quotation.

One of them was a large, powerful man, forty years of age, perhaps, with dark, chestnut-colored hair, slightly interspersed with gray. His face was full, his complexion flush, and his features grossly coarse, expressive of nothing but cruelty and cunning. He was about, of full habit, and, without prejudice (Northup, 1855: 18).
James H. Burch is noticed as poor white in this novel. He is described as slave dealer who bought Northup from Hamilton and Brown, has dark, chestnut-hair, florid skin, and wide face, and height is five feet ten inches or about $177 \mathrm{~cm}$. These features commonly owned by European, one is referred to the Irish people. Rees (1999) stated that the Irish is a reference to a dark-haired phenotype appearing in people of Irish origin. However, dark hair in people of Irish descent is common, although darker skin complexions appear less frequently. Moreover, McEvoy, B; Richards, M; Forster, P; Bradley, DG (2004) argued that there is a strong similarity between the Y chromosome haplotypes of Irish men with Goidelic surnames, and males from the area of Spain and Portugal, especially Galicia, Asturias, and Cantabria (and perhaps former Basque country). The people from these regions are generally owning the same posture as Burch owned. 
The origin of poor white in many sources informed that they were from Great Britain, especially from Ireland, Scotland and England. In the book of White Cargo: The Forgotten History of Brtiain's White Slaves in America, Jordan and Walsh (2007), said that for centuries, Ireland had been something of a special case in English colonial history. From the Anglo-Normans onward, the Irish were dehumanized, described as savages. The colonization of Ireland provided experience and drive for experiments further diverge. Under Oliver Cromwell's ethnic-cleansing policy in Ireland, unknown numbers of Catholic men, women and children were forcibly transported to the colonies. And it did not end with Cromwell, for at least another hundred years, forced transportation continued as a fact of life in Ireland. Tyler (1907) be specifically pointed to the white slaves imported to the Virginia as a part of the productive of US cities that following the cultivation in 1613 of an acceptable tobacco crop in Virginia, the need for labor accelerated. Slavery was viewed as the cheapest and most expedient way of providing the necessary work force. Due to harsh working conditions, beatings, starvation, and disease, survival rates for slaves rarely exceeded two years. Thus, the high level of demand was sustained by a continuous flow of white slaves from England, and Ireland from 1618 to 1775 , who were imported to serve America's colonial masters.

In the novel of Gone With The Wind, the picturesque of Irish inheritance could be denoted through the the protagonist scarlet Scarlet O'Hara. Scarlett is depicted a darkhaired, green-eyed as the blend blood from his father as Irishman and his mother Ellen as a woman from Savannah. Gerald O'Hara, Scarlett's father, although depicted as Master, but he commenced his life in America with nothing. He is immigrated to America from Ireland as a young man. His strong will, tendency to drink, and selfishness echo in his nature. He got his land and become white master right after marrying Ellen, Scarlett's mother. Ellen is a descendent of the aristocratic Robillard family. Ellen marries Gerald and devotes herself to running Tara after her father forbids her love affair with Philippe, her cousin. So, Gerald commenced his life in America as poor white.

The origin of poor white also come from the rest area of the Great Britain. Zee (1985) argued that in 1618, the authorities in London began to sweep up hundreds of troublesome urchins from the slums and shipped them to Virginia. England's richest man was behind this mass exclusion. It was presented as an act of charity. The "starving" children were to be given a new start as apprentices in America. This condition seemed fazing the temperament of the poor white. In Northup's Twelve Years as A Slave portrayed Burch as a poor white with unpleasant nature. He is illustrated that.

I must be allowed to say, was a man whose whole appearance was sinister and repugnant. His name was James H. Burch, as I learned afterwards - a well-known slave-dealer in Washington... (Northup, 1855: 18).

James $\mathrm{H}$ Burch represents the stereotype of the poor whites in the South as poor quality of self. Sinister and repugnant are such characters and condition of poor whites that engrained in the institution of slavery. Slavery noticeably delayed progress of whites who did not own slaves by applying a 'crowding-out effect' (Hurst, 2010) which excluded free labor in the region, rather than provide wealth as it had for the Southern white elite. Hurst (2010) conviced such stereotyoes in literature by showing the representation poor white through Harriet Beecher Stowe's novel Dred that illustrates a commonly held marriage to those poor whites results in generic degradation and barbarism of the better class.

In addition, the temperamental depiction of poor whites as sinister also possibly related to the history of the emigration of some of white European in the land of America. They were the vagrants and petty criminals who England's rulers wished to be rid of was forced to move to America. In 1572 a statue begins with the lament that allthe realm in England and Wales be presently with rogues, vagabonds, and sturdy beggars exceedingly 
pestered, it means that the daily life in England and Wales was full of murders, thefts, and other great outrage, and it makes a displeasure annoyance to the weath people (Rich, 1950). Rich (1950) stated that one of the reasons why they got rid off was the fear that England was in danger of being overwhelmed by the poor and the lawless.

So, it could be summed up that the originate of poor whites and their temperamental stereotype related to their condition and genealogy of their relocation to the new land of America. They were mostly people who got rid from the Great Britain, one of them, was Ireland. The condition of slavery made them become repulsive and minatory who expressing or conveying a threat not only for black but also for Southern white elite.

\section{Poor Whites'Social Class}

Poor white in the antebellum South as reflected in Twelve Years as A Slave are ordered in low social class. It is conveyed through their profession (job) and the relation to white master and black slaves.

Poor whites in Twelve Years As A Slave depicted as slave trader, carpenter/craft who worked for white master, and employees. They seemed free labor in glimpse, but essentially enslaved. Northup (1855: 59) depicted M. Tibeats as poor white character in his novel that "He had no fixed residence that I ever heard of, but passed from one plantation to another". This quote indicated not only the poverty suffered by poor white but also a status as enslaved people. Merritt (2017) convinced that although she certainly doesn't ever equate what poor whites and blacks endured, her research does show that a combination of slavery and surplus laborers meant that poor whites remained "unand under-employed" in system where labor was not totally free. Although poor whites were certainly not slaves, they were adversely impacted in multiple ways by the institution of slavery and the vast inequality that it produced among whites.

The profession of poor whites in Twelve Years As A Slave mostly showed as slaves dealer, carpenter, and overseer. They work for their white master as depicted in the following excerpt.

His name was James H. Burch, as I learned
afterwards-a well-known slave-dealer in
Washington, and then, or lately connected
in business, as a partner, with Theophilus
Freeman, of New-Orleans. The person
who accompanied him was a simple
lackey, named Ebenezer Radburn, who
acted merely in the capacity of turnkey
(Northup, 1855: 18).

Two poor whites in the quote are Burch and Radburn. Burch is working as a slave dealer and Ebenezer Radburn as a servant, or in Northup's stories it more like a jailer. In this novel, both of them were working in William's Slave Pen, a pen (prison) for the slaves to stay before they were sent to New Orleans. In another side, Northup also showed another profession of poor white that depicted through Tibeats, as described in the following quote.

At this time one John M. Tibeats, a carpenter, came to the opening to do some work on master's house. I was directed to quit the looms and assist him. For two weeks I was in his company, planning and matching boards for ceiling, a plastered room being a rare thing in the parish of Avoyelles. (Northup, 1855: 58).

Form the quote, it can be noticed that poor white profession in antebellum South was a carpenter that work form white master. So, although they are seemed free and independent, they are working under the control of white master. Likewise, the profession as overseer who oversee the black slaves, poor white work under the surveillance of white master. Mr. Chapin is one depicted as poor white who works as overseer in his white master plantation named Ford. Northup wrote that "Ford's overseer on this plantation, and who had the exclusive charge of it, was a Mr. Chapin, a kindly-disposed man, and a native of Pennsylvania" (Northup, 1855: 61).

In the other occasion, Northup showed the profession of poor white as laborer in the white master plantation. He was Armsby. 
Firstly, he was an overseer in his former master Mr. Shaw, but because he committed to negative traits (gambling, unprincipled man) his master compelled Armsby to become a labor. He works in the plantation together with the black slave. The following quote showed that.

At length, a low fellow, by the name of Armsby, hitherto a stranger, came into the neighborhood, seeking a situation as overseer. He applied to Epps, and was about the plantation for several days. ..His name was Armsby..

Armsby became so much reduced at last, that he was compelled to labor with the slaves. A white man working in the field is a rare and unusual spectacle on Bayou Boeuf.(Northup, 1855: 141).

The profession that the poor whites character performed is indicating that they are positioned as the lower social status people. This is related to the most basic term of selfownership as citizenship, they defined in the most basic terms of self-ownership and the basic rights were ascribed to those white elite.

Looking at the profession of poor whites, it could be denoted the relation of them to those white counterparts and black slaves. The distint representation of white master and poor white in the novel showed not only in their socio-economic status, but also the appearances to streghten di gab of their differences. The following exceprt proved that claim.

One of them was a large, powerful man, forty years of age, perhaps, with dark, chestnut-colored hair, slightly interspersed with gray. His face was full, his complexion flush, and his features grossly coarse, expressive of nothing but cruelty and cunning. He was about five feet ten inches high, of full habit, and, without prejudice, I must be allowed to say, was a man whose whole appearance was sinister and repugnant. His name was James H. Burch, as I learned afterwards - a well-known slave-dealer in Washington and then, orlately connected in business, as a partner, with Theophilus Freeman, of New-Orleans. (Northup, 1855: 18).
The description of physicall appearances of poor whites indicated the negative traits and grotesque. This is as general view of poor white in South grew more and more negative, especially in modern mass market movies and television programs. The images of appearances have become the stereotype of lower-class southern whites who share poverty status with immigrants, blacks, and other minorities (Boney, 2004). In the different langauge Glossner (2016) revealed that the negative images of poor white in the South considered as its genesis in the colonial period, became entrenched in the antebellum period, and has since become a pervasive cultural stereotype. Placing poor whites into the context of antebellum southern culture helps to illustrate why they were marginalized from southern society as well as why they posed such a problem to elite efforts at defending the southern slave labor system. In the other hand, white elite depicted positively either in appearances as well as temperament and socioeconomic status as described in the following quote.

One, a tall, thin-faced man, with light complexion and a little bent, made his appearance, with a paper in his hand. Burch's gang, consisting of myself, Eliza and her children, Harry, Lethe, and some others, who had joined us at Richmond, were consigned to him. This gentleman was Mr. Theophilus Freeman. (Northup, 1855:40).

Mr. Freeman in Twelve Years As A Slave is one of the white elite characters. $\mathrm{He}$ is depicted with such tall, thin face, light complexion, and determined, signifies he is a noble, a high class people contrasted to Burch as poor white and Northup as a black slaves. The way of Northup used the title $M r$. to Freeman is showing his respect and the way Northup explains Freeman and Burch's appearance signed the different social status of the two. The economic status also explored in the novel. Burch was a person who have small slave Dealer Company, while Freeman have bigger one. Burch was sent slaves to Freeman 
and Freeman sell slaves to the white master or slaveholders. It shows the difference status of their job, and we can say that Burch here represents the poor whites who work for the rich white person.

Compared to Solomon as black slave, poor white got better treatment. It can be seen from the relation of white master and poor white workers. They still have a warm and great cordiality in every day life. Northup depicted the relation in his novel that.

We were met at the door of Goodin's yard by that gentleman himself - a short, fat man, with a round, plump face, black hair and whiskers, and a complexion almost as dark as some of his own negroes. He had a hard, stern look, and was perhaps about fifty years of age. Burch and he met with great cordiality. They were evidently old friends. Shaking each other warmly by the hand ...(Northup, 1855: 30).

Burch and Goodin showed the cordial relation of poor white worker and white master. Goodin as the white master respect Burch as his worker. This is similarly happened to Armsby, a poor white overseer and Mr.Epps, his white master. Northup wrote that.

Presently Armsby made his appearance, and, mounting the fence, took a seat beside him. They remained two or three hours, all of which time I was in an agony of apprehension." (Northup, 1855: 142).

Burch and Armsby are depicted as overseers and labored in white planter cotton fields. The affectionate relationship among white master and the poor white labor could be seen as the effort of white masters to persuade poor white into supporting slavery through the promise of privilege under white supremacy, rather than caused by their common cultural and religious heritage. Stated by Merritt (2017) that poor whites were seen as a threat to the ruling planter class in the South, and Merritt makes clear that this relationship, heavily influenced, by the potential unity between enslaved blacks and poor whites altered the political economy of the region. Glossner (2016) conviced the same idea that the presence of a large class of poor white people in the South created a fundamental problem for the southern ruling class as it sought to shore up slavery in the face of antislavery attacks. So, the cordial relation between white master and poor white is a part of white master propaganda to elliminate a critique of the slave labor system because of their racism.

In Twelve Years As A Slave the propaganda of white masters to anti-slavery attact coming from poor white southeners displayed vividly by showing the provocative encouragement among poor white and black slaves. .

Using hatchets and broad-axes upon slaves was shameful, and should not be allowed, he remarked." This is no way of dealing with them, when first brought into the country. It will have a pernicious influence, and set them all running away. The swamps will be full of them. A little kindness would be far more effectual in restraining them, and rendering them obedient, than the use of such deadly weapons. Every planter on the bayou should frown upon such inhumanity. It is for the interest of all to do so. It is evident enough, Mr.Tibeats, that you and Platt cannot live together. You dislike him, and would not hesitate to kill him, and knowing it, he will run from you again through fear of his life. Now, Tibeats, you must sell him, or hire him out, at least. Unless you do so, I shall take measures to get him out of your possession." (Northup, 1855: 89-90).

White men, actually, have despised poor white men quite as much as some of them despised the blakcs (Negro), and have uttered their hatred with as much barbarity as they ever have against the blacks. White master, then, were heartening poor whites to hate the blacks because they could then be using to help hold the blacks in slavery. In other side, the blacks were taught to show contempt for the poor white because this would increase the hatred between them and each side could be used by the master to control them. The real interest of the poor whites and the blacks were the same, 
which of counterattacking the oppression of the white elite, then obliviousness stood in the way. This race hatred was at first used to preserve white supremacy in the South's politics. The poor whites were almost injured by it as are the blacks. Northup says in his novel that:

Burch came down into the yard, unfettered me, and led me into one of the small houses. "You told that man you came from NewYork," said he. I replied, "I told him I had been up as far as New-York, to be sure, but did not tell him I belonged there, nor that I was a freeman. I meant no harm at all, Master Burch. I would not have said it had I thought." He looked at me a moment as if he was ready to devour me, then turning round went out. In a few minutes he returned. "If ever I hear you say a word about New-York, or about your freedom, I will be the death of you-I will kill you; you may rely on that," he ejaculated fiercely. (Northup, 1855: 31).

In the above quote, Northup expressed the hatred of poor white to black. It can be evidenced that some poor whites can be so wicked to black slaves, even so racist, though they were poor also the same status as "enslaved". However the role plays of the white master to hold poor white better than black made poor white used to think and feel they were above blacks, better race, and superiority class. And also, Hollander (1935) stated it cannot be denied the facts that most of the poor whites were ignorant and immoral.

Based on the explication, it could be summed that poor white is positioned as the low social class compared to those white master, and they were subtle "enslaved' through their works. However, compared to those black slaves, poor white 'enslaved' because of their socio-economic problem, they have no capital to exist as those white master did. While blacks enslaved because of their race. It could be conveyed through the captivation of Solomon and sold as slave, instead of his status as a free black, educated, and has stable work as a carpenter and a talented violin player in the free state New York. The drama of the white master that built a cordial relation to poor white has been made poor white used to think that they are better than black and treated black worsen.

\section{CONCLUSION}

The life of poor whites in antebellum America in Solomon Northup's novel Twelve Years As A Slave reflected in subtle 'enslaved' by their whites counterpart. They depicted have an Irish look appearance and supposed to be an Irish immigrants. They also depicted have bad temperament that alleged as a fruit of their status as incarcerated people that dropped from Ireland and the rest of Great Britain to the United States. Poor white also depicted as lower social class compared to those white master. It is seen through profession as overseers, carpenters, who worked for their white master, as well as slave dealers, but higher than black slaves. The poor white people economically can be categorized as the proletariat because they were lived under the poverty and worked to the bourgeoisie (white master). However, because of the existence of white privilege, poor whites were seen themselves higher level to those black slaves. White privilege makes whites thought that they were the most powerful race in the world, so black was powerless. White privilege was set out by white master as propaganda to preserve slavery and eliminate critics towards it. White elite also built a provocation among blacks and poor white to hate each other because they were terrified of both groups joining hands. They know it's an existential threat to their power.

\section{REFERENCES}

Boney, F. N. (2016). "Poor Whites." New Georgia Encyclopedia.

Flynt, J. (2004). Wayne. Dixie's Forgotten People: The South's Poor Whites. Bloomington: Indiana UP,

Glossner, J. (2016) Cavaliers and Crackers: Landless Whites in the Mind of the Elite Antebellum South. Master's Thesis, University of Mississippi.

Hollander, A. N. J. (1935). The Tradition of 'Poor Whites. Chapel Hill, North Carolina. 
Hurst, A. L. (2010) "Beyond the Pale: Poor Whites as Uncontrolled Social Contagion in Harriet Beecher Stowe's Dred." Mississippi Quarterly 63.3/4 635-53. Academic Search Complete.

Jordan, D. \& Walsh, M. 2007. White Cargo "The Forgotten History of Britain's White Slaves in America. New York: New York University Press Washington Square.

Merritt, K. (2017). Masterless Men. In Masterless Men: Poor Whites and Slavery in the Antebellum South (Cambridge Studies on the American South, p. I). Cambridge: Cambridge University Press.

Merritt, K. (2019). Poor Whites Have Been Written out of History for a Very Political Reason. An Interview. Jacobin Online Megazine.

McEvoy, B., Richards, M., Forster, P., Bradley, DG. (2004). "Brian McEvoy, et al., "The Longue Durée of Genetic Ancestry: Multiple Genetic Marker Systems and Celtic Origins on the Atlantic Facade of Europe". American Journal of Human Genetics. 75 (4): 693-702.

Northup, S. (1855). Twelve Years As A Slave. New York: Miller, Orton, and Mulligan.

Price, A. (2004). White Trash: The Construction of An American Scapegoat. University of Virginia.
Stallard, M, (2016). "The State of Society is Awful": Poor Whites, Class, Mobility, and the Mixed-Labour Economy of New Orleans, 1820-1835. Dissertation. School of Arts, Languages and Cultures. University of Manchester.

Rees, J.L.(1999). "Pigmentation, melanocortins and red hair. 'Do freckles and red hair help Irishmen catch leprechauns?'”. Quarterly Journal of Medicine. 92 (3): 125-131.

Rich, E. E. (1950). The Population of Elizabethan England'in The Economic History Review, NewSeries, Vol. 2, No. 3.

Seabrook, E. B. (Web. 10 July 2012). Poor Whites of the South." The Galaxy Volume. p. 681-691 04 Issue 6..

Swingewood, A. \& Laurenson, A. (1972). Sociology of Literature. London: Granada Publishing Limit.

Tyler. (1907). Narrratives of Early Virginia 1606-1625. Lyon Gardiner.

Wellek, R. \& Warren, A. (1976). Theory of Literature. Harcourt, Brace, and Company.

Weston, G. M. (Web. 10 July 2012). Poor Whites of the South. Washington: Republican Executive Congressional Committee.

Wray, M. (2006). "Not Quite White: White Trash and the Boundaries of Whiteness. Duke University Press

Zee, Van der J. (1985). Bound Over: Indentured Servitude and American Conscience. 